\title{
PERBANDINGAN EFISIENSI PADA INDUSTRI ASURANSI JIWA SYARIAH DAN KONVENSIONAL DENGAN DATA ENVELOPMENT ANALYSIS (DEA)
}

\author{
Foza Hadyu Hasanatina \\ fozahadyu04@gmail.com \\ Risanda A. Budiantoro \\ Vicky Oktavia \\ Program Studi Manajemen Fakultas Ekonomi dan Bisnis, Universitas Dian Nuswantoro
}

\begin{abstract}
This study aims to anlyze and comparing the efficiency of Islamic Life Insurance and Conventional Life Insurance in Indonesia. This study uses a quantitative non-parametric approach with Data Envelopment Analysis (DEA) with the assumption of Constant Return to Scale (CRS) and Variable Return to Scale (VRS) with input and output orientation. The samples are 3 Islamic Life Insurance (full fledge) and 3 Conventional Life Insurance that comply with the specified sample criteria during 2012-2019. The input variables used ared cost of commissive, operational cost, total equity, while the output variables is the premi income, and investment revenue. The results of the study indicate that the average result of DEA analysis for the entire DMU (Decision Making Unit) has not been efficient. In Conventional Life Insurance, the value of economic efficiency by 64,82 percent, technically efficiency for72,22 percent, and scale efficiency 81,4 percent, while in Islamic Life Insurance, the value of economic efficiency by 17,26 percent, technically efficiency for 53,71 persen, and scale efficiency 47,41 percent. Source of inefficiency Conventional and Islamic Life Insurance company is the sacle of operations and management of input to output is not optimal.
\end{abstract}

Key words: efficiency; conventional life insurance; islamic life insurance; DEA

\begin{abstract}
ABSTRAK
Penelitian ini bertujuan untuk menganalisis dan melakukan perbandingan atas efisiensi asuransi jiwa Islam dengan asuransi jiwa konvensional di Indonesia. Penelitian ini menggunakan metode kuantitatif dengan pendeketan non prarametrik Data Envelopment Analysis (DEA) asumsi Constant Return to Scale (CRS) and Variable Return to Scale (VRS) dengan berorientasi input-output. Sampel yang digunakan sebanyak tiga asuransi jiwa Islam dan tiga asuransi jiwa konvensional yang memenuhi kriteria sampel yang ditentukan selama 2012-2019. Variabel input yang digunakan biaya komisif, biaya operasional, dan total ekuitas, sedangkan variabel outputnya adalah pendapatan premi, dan pendapatan investasi. Hasil penilitiannya menunjukkan bahwa rata-rata berdasarkan analisis DEA untuk seluruh DMU (Decision Making Unit) belum efisien. Dalam Asuransi Jiwa Konvensional, nilai efisiensi ekonomi sebesar 64,82 persen, untuk efisiensi teknis sebesar 72,22 persen, dan skala efisiensi sebesar 81,4 persen, sedangkan dalam Asuransi Jiwa Islam, nilai efisiensi ekonomi sebesar 17,26 persen, untuk efisiensi teknis sebesar 53,71 persen, dan skala efisiensi 47,41 persen. Sumber inefisiensi Perusahaan Asuransi Jiwa Konvensional dan Islami adalah tingkat operasi dan manajemen input ke output yang tidak optimal.
\end{abstract}

Kata kunci: efisiensi; asuransi jiwa konvensional; asuransi jiwa islam; DEA

\section{PENDAHULUAN}

Kemajuan ilmu pengetahuan dan teknologi saat ini membuat manusia tampak mengalami kemajuan dalam menjalani kehidupan secara ekonomi. Namun, bila kita lihat secara nyata bahwa sebenarnya 
kemajuan yang selama ini terjadi masih mengalami kemunduran. Indikator yang dapat digunakan ialah pada pertumbuhan ekonomi yang tidak merata oleh setiap masyarakat, dimana yang kaya semakin kaya dan yang miskin masih berkutat dengan kemiskinannya. Perekonomian dunia masih didominasi oleh Negara-negara Eropa dan Amerika Serikat dengan sistem ekonomi konvensionalnya dan memaksa Negara maju lainnya termasuk Negara berkembang untuk menerapkan sistem ekonomi yang sama berbasis bunga termasuk dalam industri asuransi yang seringkali menciptakan permasalahan tersendiri berupa keresahan, ketidakpastian, dan ketidak adilan kepada para nasabahnya.

Perkembangan saat ini terdapat dua jenis asuransi yaitu asuransi konvensional dan asuransi syariah. Sebenarnya kedua jenis asuransi tersebut tidak terlalu beda jauh namun memang ada beberapa hal yang bertolak belakang sehingga perlu ada beberapa hal yang harus disesuaikan terlebih dahulu. Asuransi konvensional dimulai dari masyarakat Babilonia 4.000-3.000 SM dan itu dulu disebut dengan perjanjian Hammurabi. Asuransi sendiri masuk ke Indonesia pada masa zaman penjajahan Belanda. Hadirnya keberadaan asuransi di Indonesia akibat dari berhasilnya Belanda dalam sektor perkebunan dan perdagangan di Indonesia pada masa tersebut.

Asuransi syariah sudah dikenal pada zaman Rasulullah yang dikenal dulu sebagai sistem Al-Aqilah. Ide pokok dari Aqilah sendiri adalah suku Arab zaman dahulu harus melakukan kontribusi finansial atas Nama yang bertanggung jawab untuk membayar pewaris yang di tanggung jawabkan. Sistem ini dulu sudah menjadi kebiasaan suku Arab sebelum masuknya Islam dan kemudian disahkan oleh Rasulullah sebagai hukum Islam yang dibuat oleh Rasulullah dalam bentuk konstitusi pertama di dunia. Asuransi syariah di Indonesia diawali. Pada tahun 1994. Dan pada saat itu asuransi syariah yang pertama kali hadir di Indonesia itu adalah PT. Syarikat Takaful Indonesia pada tanggal 24 Februari 1994 yang dimotori oleh lembaga Ikatan Cendikiawan.

Industri asuransi merupakan salah satu dari Industri Keuangan Non Bank yang mengalami peningkatan dalam pertumbuhannya. Perusahaan asuransi menurut Undang-Undang No.40 tahun 2014 tentang Perasuransian adalah perjanjian antar dua pihak, dengan mana pihak penanggung mengikatkan diri kepada tertanggung, dengan menerima premi asuransi, untuk memberikan penggantian kepada tertanggung karena kerugian, kerusakan atau kehilangan keuntungan yang diharapkan atau tanggung jawab hukum kepada pihak ketiga yang mungkin akan diderita tertanggung, yang timbul dari suatu peristiwa yang tidak pasti atau untuk memberikan suatu pembayaran yang didasarkan atas meningggal atau hidupnya seseorang dipertanggungkan. Menurut Fatwa DSN No: 21/DSN-MUI/X/2001 tentang Pedoman Umum Asuransi Syariah, definisi dari Asuransi Syariah tersebut adalah usaha saling melindungi dan tolong menolong di antara sejumlah orang atau pihak melalui investasi dalam bentuk aset atau tabarru' yang memberikan pola pengembalian untuk menghadapi risiko tertentu melalui akad yang sesuai dengan syariah. Industri asuransi syariah memiliki peran penting dalam pembangunan ekonomi dengan meminimalisir risiko pada semua aktivitas ekonomi.

Pada Januari 2020, tercatat jumlah industri asuransi di Indonesia sebanyak 151 industri, yang terbagi dalam industri asuransi konvensional sebanyak 138 industri dan asuransi syariah sebanyak 13 industri. Berdasarkan data statistik Industri Keuangan Non Bank (IKNB) yang dirilis OJK, pada tahun 2012-2019 total asset asuransi konvensional terus meningkat mulai dari 239,790 Triliun pada tahun 2012 hingga mencapai nilai 586,166 Triliun pada tahun 2019, begitu pula dengan total asset asuransi syariah yang terus meningkat dari tahun ke tahun walaupun jumlahnya masih jauh jika dibandingkan dengan asuransi konvensi- 
onal. Pada tahun 2012 total asset asuransi syariah bernilai 13,240 triliun dan terus meningkat mencapai Rp 44,212 triliun pada tahun 2019. Pertumbuhan asset tersebut didominasi oleh petumbuhan asset asuransi jiwa. Jika dilihat pada 2019, asset asuransi jiwa konvensional 92,99 persen dari total asset asuransi keseluruhan dan asset asuransi jiwa syariah 7,01 persen dari total asset asuransi keseluruhan. Pertumbuhan total asset yang ditunjukkan oleh asuransi konvensional dan syariah dari tahun ke tahun mulai 2012 sampai 2019 dapat dilihat dari tabel berikut:

Tabel 1

Aset Asuransi Jiwa Konvensional dan Syariah

\begin{tabular}{lcccccccc}
\hline \multicolumn{7}{c}{ Total Asset Asuransi Jiwa Konvensional dan Syariah (dalam triliun rupiah) } \\
\hline \multicolumn{1}{c}{ Keterangan } & $\mathbf{2 0 1 2}$ & $\mathbf{2 0 1 3}$ & $\mathbf{2 0 1 4}$ & $\mathbf{2 0 1 5}$ & $\mathbf{2 0 1 6}$ & $\mathbf{2 0 1 7}$ & $\mathbf{2 0 1 8}$ & $\mathbf{2 0 1 9}$ \\
\hline $\begin{array}{l}\text { Total Asset } \\
\text { Asuransi Jiwa }\end{array}$ & 239,790 & 253,210 & 318,210 & 318,490 & 327,680 & 512,940 & 580,820 & 586,166 \\
$\begin{array}{l}\text { Konvensional } \\
\text { Growth }\end{array}$ & & $5,30 \%$ & $20,43 \%$ & $0,09 \%$ & $2,80 \%$ & $36,12 \%$ & $11,69 \%$ & $0,91 \%$ \\
$\begin{array}{l}\text { Total Asset } \\
\begin{array}{l}\text { Asuransi Jiwa } \\
\text { Syariah }\end{array}\end{array}$ & 13,240 & 16,650 & 22,380 & 26,690 & 33,120 & 33,490 & 39,759 & 44,212 \\
Growth & & $20,48 \%$ & $25,60 \%$ & $16,15 \%$ & $19,41 \%$ & $1,10 \%$ & $15,77 \%$ & $10,07 \%$ \\
\hline
\end{tabular}

Sumber: Otoritas Jasa Keuangan (2019), diolah lebih lanjut oleh penulis

Dari Tabel 1 di atas dapat dilihat perbandingan total aset asuransi jiwa konvensional dan asuransi syariah. Dalam pertumbuhannya, total aset asuransi jiwa baik konvensional dan asuransi jiwa syariah terus mengalami peningkatan yang cukup pesat bila dibandingkan dengan jenis asuransi lainnya. Selain dilihat dari jumlah asetnya, dapat diidentifikasi bahwa per- tumbuhan kontribusi bruto terhadap perekonomian Negara pada asuransi jiwa konvensional mengalami peningkatan yang cukup signifikan bila dibandingkan dengan asuransi umum syariah, serta nilainya juga memiliki perbedaan yang sangat signifikan. Kontribusi bruto asuransi syariah terhadap perekonomian Indonesia dapat dilihat pada tabel dibawah ini:

Tabel 2

Pertumbuhan Kontribusi Bruto Asuransi Syariah di Indonesia

\begin{tabular}{ccc}
\hline \hline Keterangan & Asuransi Jiwa Syariah & Asuransi Umum Syariah \\
\hline 2012 & 5,2 & 1,74 \\
2013 & 7,19 & 1,82 \\
2014 & 8,39 & 1,61 \\
2015 & 8,27 & 1,96 \\
2016 & 9,44 & 2,87 \\
2017 & 9,98 & 2,94 \\
2018 & 10,505 & 3,57 \\
2019 & 11,36 & 4,06 \\
\hline
\end{tabular}

Sumber: Otoritas Jasa Keuangan (2019), diolah lebih lanjut oleh penulis

Dari Tabel 2 di atas dapat dilihat bahwa pertumbuhan kontribusi bruto pada asuransi jiwa syariah lebih besar daripada asuransi umum syariah yang menunjukkan bahwa asuransi jiwa syariah memiliki peran yang besar dalam perkembangan industri 
asuransi Syariah di Indonesia. Hal ini dikarenakan masyarakat lebih membutuhkan

asuransi pada kondisi jiwa mereka dibandingan dengan hal-hal yang lainnya.

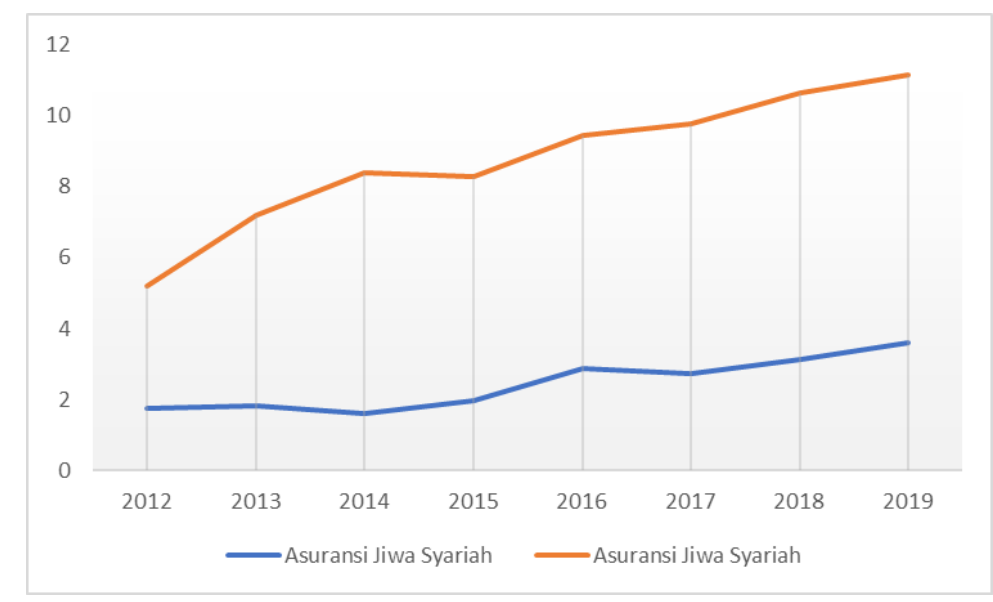

\section{Gambar 1}

Pertumbuhan Kontribusi Bruto Asuransi Syariah

Sumber: Otoritas Jasa Keuangan (2019), data diolah penulis

Penilaian tingkat efisiensi pada suatu industri asuransi baik itu konvensional dan syariah bertujuan untuk mengetahui bagaimana kemampuan manajerial perusahaan asuransi jiwa syariah dalam mengelola perusahaannya. Selain itu, pengukuran efisiensi sangat penting dalam melihat kemampuan asuransi jiwa syariah untuk bertahan dan menghadapi ketatnya persaingan pada industri asuransi jiwa syariah maupun pada industri asuransi konvensional. Dengan mengetahui tingkat efisiensi itu pula, para nasabah asuransi jiwa syariah dapat menilai kinerja perusahaan asuransi jiwa syariah tersebut sehingga dapat meningkat tingkat kepercayaan nasabah.

Saad et al. (2006); Aliyu dan Yusof (2016) mengukur efisiensi industri asuransi di Malaysia periode 2002-2005 pada 13 perusahaan asuransi jiwa baik asuransi konvensional maupun perusahaan takaful. Di mana input yang digunakan adalah biaya komisi dan biaya manajemen. Sedangkan variabel outputnya adalah premi dan pedapatan investasi. Tuffahati et al. (2016) mengukur efisiensi asuransi syariah dengan DEA. Hasil penelitian menunjukkan bahwa sumber inefisiensi pada perusahaan asuransi syariah di Indonesia terdapat pada empat variabel yaitu total asset, biaya komisi, kontribusi bruto dan pendapatan investasi. membandingkan tingkat efesiensi syariah dan konvensional di Indonesia. Hasil penelitiannya menjelaskan bahwa tingkat efesiensi perusahaan asuransi syariah pada kelompok perusahaan asuransi umum syariah tidak ada yang mencapai tingkat efisien.

Teknik pengukuran efisiensi dapat dilakukan melalui pendekatan frontier, yang mengukur efisiensi melalui dua jenis pendekatan yaitu parametrik dan nonparametrik. Analisis parametrik menghasilkan cost frontier yang dapat diukur dengan metode Stocastic Frontier Analysis (SFA) dan Distribution Free Analysis (DFA), sedangkan analisis nonparametrik menghasilkan production frontier yang dapat diukur dengan metode Data Envelopment Analysis (DEA) (Muharam dan Pusvitasari, 2007; Putri dan Mulazid, 2017). DEA merupakan alat analisis yang relatif baik digunakan untuk mengukur efisiensi pada organisasi profit oriented maupun non-profit oriented yang dalam proses produksi atau aktivitasnya melibatkan penggunaan input untuk menghasilkan output (Galiniene dan Dzemydaite, 2012; Sabiti et al., 2017). 
Berdasarkan hasil penelitian yang sudah dilakukan, studi efisiensi ini sudah berlangsung selama dua atau tiga dekade terakhir. Namun, sebagian besar masih terfokus pada pengukuran efisiensi perbankan baik konvensional dan syariah di Indonesia. Seperti yang dilakukan oleh Rosman et al. (2013); Novandra (2014); Aliyu dan Yusof (2016); Miah dan Udin (2017); dan Alqahtani, Mayes dan Brown (2017). Atas dasar pemikiran tersebut maka studi ini akan melihat sejauh mana tingkat efisiensi pada asuransi baik konvensional dan syariah. Harapannya dari hasil studi ini dapat dijadikan acuan bagi pihak-pihak terkait untuk terus mengoptimalkan potensi yang dimiliki oleh asuransi sehingga dapat beroperasi lebih efisien kedepannya.

Penelitian ini bertujuan untuk mengetahui beberapa hal yaitu, bagaimana kondisi tingkat efisiensi industri asuransi jiwa di Indonesia, dan bagaimana perbandingan tingkat efisiensi asuransi jiwa konvensional dan asuransi jiwa syariah. Adapun objek penelitian yang diambil adalah perusahaan asuransi yang memiliki laporan keuangan lengkap dari 2012-2019. Untuk asuransi konvensional terdiri dari tiga asuransi jiwa konvensional yaitu PT. Asuransi Jiwasraya (Persero), PT. Asuransi Prudential Life Assurance, dan PT. Axa Life Indonesia. Sedangkan untuk asuransi jiwa syariah terdiri dari PT. Asuransi Takaful Keluarga, PT. Asuransi Jiwa Syariah Al-Amin, dan PT. Asuransi Jiwa Syariah Amanahjiwa Giri Artha.

\section{TINJAUAN TEORETIS \\ Lembaga Keuangan}

Menurut Abror, Santi dan Frianto (2005) lembaga keuangan adalah suatu lembaga perantara dari pihak yang memiliki dana lebih pada saat tertentu kepada pihak yang membutuhkan dana pada suatu saat tertentu pula. Lembaga ini berupa bank, lembaga keuangan bukan bank atau lembaga keuangan atau pembiayaan lainnya. Fungsi lembaga keuangan tersebut adalah menyelesaikan transaksi dalam mekanisme pembayaran, perdagangan sekuritas, transmutasi, diversifikasi, risiko, dan manajemen portofolio. Bank umum turut serta dalam lalulintas giral sedangkan lembaga keuangan bukan bank.

Lembaga keuangan memiliki fungsi sebagai lembaga yang mempercepat penyaluran dana-dana dari Surplus Spending Unit (SSU) ke Deficit Spending Unit (DSU). Fungsi ini dikenal sebagai fungsi perantara finansial (finansial intermediaton). Selain fungsi tersebut masih ada lagi fungsi atau peran lain yang hampir identik dengannya, yaitu sebagai agent of development. Agent of development ini berfungsi sebagai lembaga yang memobilisasi dana untuk pembangunan ekonomi. Dengan fungsi-fungsi ini lembaga keuangan dapat mendorong pengembangan dan pembangunan ekonomi suatu daerah atau suatu negara. Lembaga keuangan dapat memobilisasi dana dari masyarakat atau dari luar daerah yang kemudian di salurankan kembali kedalam perekonomian dalam bentuk kredit (Winarno, 2015).

\section{Asuransi Konvensional}

Menurut Wirdyaningsih (2005) asuransi itu sendiri diambil dari bahasa Belanda yaitu assurantie. Dalam hukum belanda disebut dengan verzekering, yang berarti pertanggungan, yang dimaksud dengan asuransi atau pertanggungan adalah perjanjian antara dua pihak atau lebih, dengan mana pihak penanggung mengikatkan diri kepada tertanggung, dengan menerima premi asuransi, untuk memberikan penggantian kepada tertanggung karena kerugian, kerusakan, atau kehilangan keuntungan yang diharapkan, atau tanggung jawab hukum kepada pihak ketiga yang mungkin akan diderita tertanggung, yang timbul dari suatu peristiwa yang tidak pasti, atau untuk memberikan suatu pembayaran yang didasarkan atas meninggal atau hidupya seseorang yang dipertanggungkan. Menurut Kitab UndangUndang Hukum Dagang (KUHD), tentang asuransi atau pertanggungan seumurnya, Bab 9, Pasal 246, asuransi atau pertanggu- 
ngan adalah suatu perjanjian dengan mana seorang penanggung mengikatkan diri kepada seorang tertanggung, dengan menerima suatu premi, untuk memberikan penggantian kepadanya karena suatu kerugian, kerusakan atau kehilangan keuntu ngan yang diharapkan, yang mungkin akan dideritanya karena suatu peristiwa yang tak tertentu.

\section{Konsep Dasar Asuransi Syariah}

Asuransi dalam bahasa Arab disebut attaimin yang memiliki arti memberi perlindungan, ketenangan, rasa aman, dan bebas dari rasa takut, sebagaimana dalam firman Allah,

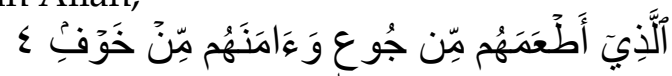

Artinya: "Yang telah memberi makanan kepada mereka untuk menghilangkan lapar dan mengamankan mereka dari ketakutan" QS. Qurasysh (106) : 4.

Menurut Fatwa DSN No. 21/DSNMUI/2001 tentang pedoman umum asuransi syariah, asuransi syariah (Ta'min, Takaful atau Tadhamun) adalah usaha saling melindungi dan tolong-menolong di antara sejumlah orang atau pihak melalui investasi dalam bentuk asset atau tabarru' yang memberikan pola pengembalian untuk menghadapi risiko tertentu melalui akad (perikatan) yang sesuai dengan syariah. Akad yang dipakai dalam asuransi syariah yaitu akad tijarah dan akad tabarru'. Akad tijarah merupakan semua bentuk akad yang dilakukan untuk tujuan komesial (mudharabah). Sedangkan akan tabarru' merupakan semua bentuk akad yang dilakukan dengan tujuan kebajikan dan tolong-menolong, bukan semata untuk tujuan komersial (hibah).

Perusahaan asuransi dalam konsep asuransi syariah hanya bertindak sebagai pengelola dana tabarru' atau kontribusi peserta bukan sebagai pemilik kontribusi (Ningsih dan Suprayogi, 2017). Mekanisme pengelolaan dana tabarru' dalam asuransi syariah ini dibagi menjadi dua sistem, diantaranya sistem yang mengandung tabu- ngan dan sistem yang tidak mengandung tabungan (Muhammad, 2007: 88).

Berdasarkan hukum positif, hingga saat ini asuransi syariah masih mendasarkan legalitasnya pada Undang-Undang No. 2 tahun 1992 tentang perasuransian. Dalam Kitab Undang-undang Hukum Dagang Pasal 246, yaitu: "Asuransi adalah suatu perjanjian dimana seseorang penanggung mengikatkan diri kepada seorang tertanggung dengan menerima suatu premi, untuk memberikan penggantian kepadanya karena suatu kerugian, kerusakan atau kehilangan keuntungan yang diharapkan yang mungkin akan dideritanya karena suatu peristiwa yang tak tentu" (ahmad dan Hamid, 2005).

Ahmad dan Hamid, (2005) selanjutnya menegaskan bahwa pengertian diatas tidak dapat dijadikan landasan hukum yang kuat bagi Asuransi Syariah karena tidak mengatur keberadaan asuransi berdasarkan prinsip syariah, serta tidak mengatur teknis pelaksanaan kegiatan asuransi dalam kaitannya kegiatan administrasinya. Pedoman untuk menjalankan usaha asuransi syariah terdapat dalam Fatwa Dewan Asuransi Syariah Nasional Majelis Ulama Indonesia (DSN-MUI) No.21/DSN-MUI/X/2001 tentang Pedoman Umum Asuransi Syariah tersebut tidak memiliki kekuatan hukum dalam Hukum Nasional karena tidak termasuk dalam peraturan perundang-undangan di Indonesia. Maka agar ketentuan Asuransi Syariah memiliki kekuatan hukum perlu dibentuk peraturan yang termasuk peraturan perundang-undangan yang ada di Indonesia meskipun dirasa belum memberi kepastian hukum yang lebih kuat dan peraturan tersebut yaitu Keputusan Menteri Keuangan RI No.426/KMK.06/2003, Keputu san Menteri Keuangan RI No. 424/KMK. 06/2003 dan Keputusan Direktorat Jendral Lembaga Keuangan No. 4499/LK/2000. Semua keputusan tersebut menyebutkan mengenai peraturan sistem asuransi berbasis Syariah (Amrin, 2006).

Shahibul maal meminta kepada mudharib untuk mengelola dananya, namun dengan syarat bahwa nisbah bagi hasil yang 
akan dihasilkan dibagi dua 90\% untuk shahibul maal dan $10 \%$ untuk mudharib (Ali, 2008). Secara fiqh, akad mudharabah yang dilakukan oleh kedua belah pihak di atas adalah sah. Karena telah memenuhi semua rukun dan syarat akad mudharabah. Namun secara "nilai", akad tersebut cacat karena tidak memberikan porsi keadilan bagi mudhari beban. Mudharib hanya mendapatkan keuntungan $10 \%$ sementara shahibul maal 90\%. Untuk itulah dalam menjalankan usaha asuransi syariah, juga sangat diperlukan tegaknya nilai-nilai syariah, agar operasional asuransi syariah benar-benar mencerminkan ruh syariah yang sesungguhnya.

\section{Konsep Efisiensi}

Menurut Archer (2010), efisiensi merupakan ukuran efektivitas yang menghasilkan peminimalisiran waktu, tenaga, dan keterampilan yang terbuang. Secara umum efesiensi merupakan perbandingan antara variabel input dan output. Dalam hal ini, suatu perusahaan dapat dikatakan efisien bila mampu memaksimalkan output dengan menggunakan input yang tetap ataupun dengan meminimalkan penggunaan input untuk mencapai tingkat output yang sama (Karim, 2007).

Penjelasan efisiensi dalam konsep ekonomi ialah merujuk pada konsep yang berkaitan dengan penggunaan, pemaksimalan, serta pemanfaatan seluruh sumber daya yang dimiliki untuk menyelenggarakan proses produksi berupa barang dan atau jasa (Utama et al., 2016). Sedangkan penjelasan efisiensi dalam konsep produksi akan merujuk pada sejauh mana hubungan teknis dengan penyelenggaraan kegiatan operasional dalam suatu proses produksi seperti konversi variabel input menjadi output (Dewi dan Siauwijaya, 2016; Sutawijaya dan Lestari, 2009). Proses kegiatan operasional dalam APBDes dikatakan efisien apabila produk atau hasil kerja tertentu dapat dicapai dengan menggunakan sumber daya yang minimum (Tumbel, 2014).
Menurut Farrel (1957), efisiensi suatu perusahaan terdiri dari dua komponen, yaitu efisiensi teknik dan efisiensi alokatif. Efisiensi teknis merupakan efisiensi yang menggambarkan kemampuan suatu perusahaan untuk mencapai level output yang optimal dengan menggunakan tingkat input tertentu. Efisiensi alokatif merupakan efisiensi yang menggambarkan kemampuan suatu per usahaan dalam mengoptimalkan penggunaan inputnya dengan struktur harga dan teknologinya. Kedua komponen tersebut dikombinasikan untuk menghasilkan efisiensi total atau efisiensi ekonomis. Efisiensi ekonomis merupakan efisiensi yang menggambarkan kemampuan perusahaan dalam meminimalkan biaya produksi untuk menghasilkan output tertentu dengan suatu tingkat teknologi yang umumnya digunakan serta harga yang berlaku (Rusydiana dan Nugroho, 2017).

Menurut Muharam dan Pusvitasari (2007), terdapat tiga jenis pendekatan untuk mengukur efisiensi, di antaranya:

\section{a. Pendekatan Rasio}

Pendekatan rasio merupakan pendekatan dengan membandingkan input yang digunakan dengan output yang dihasilkan. Dalam pendekatan ini, efisiensi yang tinggi apabila dapat memproduksi jumlah output yang maksimal dengan input yang seminimal mungkin.

$$
\text { Efisiensi }=\frac{\text { Output }(y)}{\text { Input }(x)}
$$

\section{b. Pendekatan Regresi}

Pendekatan regresi merupakan pendekatan mengukur efisiensi dengan menggunakan metode dari tingkat output tertentu sebagai fungsi dari tingkat input tertentu. Persamaan regresi dapat ditulis dengan fungsi sebagai berikut:

$$
\mathrm{Y}=\left(\mathrm{X}_{1}, \mathrm{X}_{2}, \mathrm{X}_{3}, \mathrm{X}_{4, \ldots,} \mathrm{X}_{\mathrm{n}}\right)
$$

Dimana $Y=$ Output, dan $X=$ Input

Dalam pendekatan ini, efisiensi akan dinilai apabila dapat menghasilkan output lebih banyak dibandingkan dengan estimasinya. Akan tetapi dalam pendekatan ini 
tidak dapat mengukur efisiensi dengan jumlah output yang banyak, karena hanya satu output yang bisa menjadi indikator.

\section{c. Pendekatan Frontier}

Dalam pendekatan Frontier untuk mengukur efisiensi dibedakan menjadi dua jenis, yaitu pendekatan Frontier Parametric (SFA dan DFA) dan nonparametric (DEA).

Selain ketiga pendekatan di atas, terdapat dua jenis model pendekatan yang dapat digunakan dalam industri asuransi, antara lain (Rusydiana dan Nugroho, 2017):

1) Pendekatan Operasional (produksi) yaitu pendekatan yang menggambarkan asuransi sebagai produsen atas jasa. Yang digunakan dalam pendekatan ini seperti gaji dan berbagai pengeluaran untuk memenuhi pendanaan pada pemegang polis dan menyediakan jasa kerugian bagi klien (nasabah asuransi).

2) Pendekatan Investasi (Intermediasi) yaitu pendekatan yang menggabarkan bahwa perusahaan asuransi yang diperoleh bertindak sebagai intermediary. Dana yang terkumpul dari premi sejak periode awal asuransi yang diperoleh sepanjang tahun dan tidak ditetapkan sebagai alokasi klaim, maka di investasikan pada obligasi dan saham. Tujuan pendekatan ini adalah untuk mengukur tingkat kemampuan perushaan dalam menghasilkan sejumlah return dalam kegiatan asuransi.

Dalam ekonomi Islam, konsep efisiensi berkaitan dengan cara untuk menjaga salah satu maqashid syariah yaitu al-maal (harta). Dalam Islam sangat dianjurkan untuk memelihara harta yang kita miliki dengan tidak berlaku boros. Hal ini seperti tercermin dalam firman Allah SWT, yaitu:

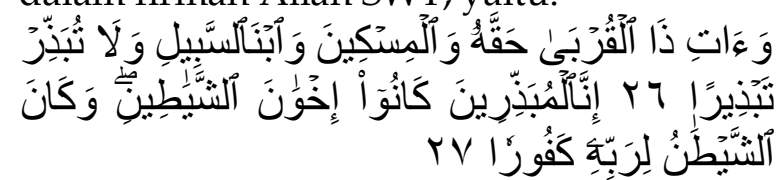

Artinya: “26. Dan berikanlah kepada keluarga-keluarga yang dekat akan haknya, kepada orang miskin dan orang yang dalam perjalanan dan janganlah kamu menghambur- hamburkan (hartamu) secara boros, 27. Sesungguhnya pemboros-pemboros itu adalah saudarasaudara syaitan dan syaitan itu adalah sangat ingkar kepada Tuhannya" QS. Al-Israa' (17) : 26-27.

Dalam tafsir Ibnu Katsir, maksud dari ayat di atas adalah Allah SWT memberikan perintah bagi hamba-Nya untuk memberi nafkah kepada orang-orang miskin dan ibnu sabil. Allah SWT melarang bagi hamba-Nya untuk bersikap berlebih-lebihan dalam memberi nafkah (membelanjakan harta), dan tidak pula bersifat kikir. Kemudian Allah SWT berfitman untuk menanamkan rasa antipati terhadap sikap pemborosan dan berlebih-lebihan. Manusia yang melakukan pemborosan adalah saudara setan.

Dalam menjalankan suatu usaha, Islam mengharuskan kaffah dalam menjalankan setiap aktivitas, namun dengan tidak melanggar batasan-batasan yang telah ditetapkan oleh Allah SWT agar hasil yang didapatkan nantinya akan optimal dan tidak ada yang dirugikan atau terdzalimi.

\section{METODE PENELITIAN}

\section{Jenis dan Sumber Data}

Jenis penelitian ini adalah kuantitatif dengan menggunakan data sekunder selama periode 2012-2019 yang telah dipublikasikan sebagai data utama yang didapat dari laporan keuangan masing-masing perusahaan asuransi. Objek penelitian ini adalah enam perusahaan asuransi jiwa di Indonesia yang terdiri dari tiga perusahaan asuransi jiwa konvensional dan tiga perusahaan asuransi jiwa syariah yang bukan merupakan unit usaha perusahaan konvensional. ketiga perusahaan asuransi jiwa konvensional adalah PT. Asuransi Jiwasraya (Persero), PT. Asuransi Prudential Life Assurance, dan PT. Axa Life Indonesia. Sedangkan perusahaan asuransi jiwa syariah terdiri dari PT. Asuransi takaful Keluarga, PT. Asuransi Jiwa Syariah Al-Amin, dan PT. Asuransi Jiwa Syariah Amanahjiwa Giri Artha. Teknik sampling pada penelitian ini menggunakan non-probability sampling dengan purposive sampling. 


\section{Alat Analisis}

Penelitian ini menggunakan metode Data Envelopment Analysis (DEA). DEA merupakan sebuah teknik aplikasi program linier yang mengukur efisiensi relatif dari setiap unit produksi dibandingkan dengan unit produksi lainnya yang memiliki tujuan yang sama (Faruk dan Rahaman, 2015; Benarda et al., 2016; Ningsih dan Suprayogi, 2017). Unit produksi yang digunakan dalam metode ini disebut dengan Decision-Making Unit (DMU). Metode DEA dirancang untuk mengukur efisiensi relatif DMU dibandingkan dengan DMU lain dalam sampel yang menggunakan jenis input dan output yang sama.

Metode Data Envelopment Analysis juga merupakan metode non-parametrik berbasis program linier yang mengukur rasio efisiensi antara input dan output pada Unit Kegiatan Ekonomi (UKE). DEA termasuk salah satu alat analisis non-parametrik yang digunakan untuk mengukur efisiensi secara relatif baik antar organisasi bisnis yang berorientasi laba (profit oriented) maupun antar organisasi atau pelaku kegiatan ekonomi yang tidak berorientasi laba (nonprofit oriented) yang dalam proses produksi atau aktivitasnya melibatkan penggunaan input-input tertentu untuk menghasilkan output-output tertentu. Alat analisis ini juga dapat mengukur efisiensi basis dan alat pengambil kebijakan dalam peningkatan efisiensi (Banker et al., 2012).

Ada tiga manfaat yang diperoleh dari pengukuran efisiensi DEA antara lain sebagai tolak ukur untuk memperoleh efisiensi relatif yang berguna untuk mempermudah perbandingan antara unit ekonomi yang sama, mengukur berbagai variasi efisiensi antar unit ekonomi untuk mengidentifikasi faktor-faktor apa saja yang menjadi penyebabnya, dan menentukan implikasi kebijakan, sehingga dapat meningkatkan nilai efisiensinya. DEA menghasilkan skor efisiensi berkisar antara 0-100 persen, dan
DMU yang memiliki skor kurang dari 100 persen dianggap sebagai unit yang relatif tidak efisien. Model DEA dibagi menjadi dua, yaitu:

a. Model Constant Return to Scale (CRS)

Model CRS dikembangkan oleh Charnes et al. (1978) yang awalnya lebih dikenal dengan model CCR. Model ini menggunakan asumsi bahwa rasio antara penambahan input dan output sama, yang berarti bahwa jika terdapat tambahan input maka output juga akan meningkat. Setiap DMU pada model ini beroperasi pada skala yang optimal. Pengukuran efisiensi menggunakan model CRS adalah pengukuran secara overall technical efficiency (OTE) atau pengukuran efisiensi kotor (gross eficiency) yang merupakan perpaduan antara efisiensi teknis dan skala.

\section{b. Model Variable Return to Scale (VRS)}

Model VRS atau BCC dikembangkan oleh Banker, Charnes, dan Cooper (1978) yang merupakan pengembangan dari model CCR. Model ini berasumsi bahwa perusahaan belum atau tidak beroperasi dalam skala optimal sehingga rasio antara penambahan input dan output tidak sama, yang berarti penambahan input tidak akan meningkatkan output. Pengukuran efisiensi dengan VRS membedakan nilai efisiensi menjadi dua, yaitu pure technical efficiency (PTE) dan efisiensi skala.

Terdapat tiga manfaat yang didapat dari pengukuran efisiensi dengan DEA, yaitu: (1) sebagai tolak ukur untuk memperoleh efisiensi relatif yang berguna untuk memudahkan perbandingan antara unit ekonomi yang sama; (2) mengukur berbagai efisiensi antara unit ekonomi untuk mengidentifikasi faktor penyebabnya; (3) untuk menentukan implikasi kebijakan sehingga dapat meningkatkan efisiensinya.

Variabel yang digunakan dalam penelitian ini mengacu pada variabel input dan output yang terdapat dalam penelitianpenelitian terdahulu, seperti dalam Tabel 3 dan 4 di bawah ini. 
Variabel Input Penelitian

\begin{tabular}{|c|c|c|}
\hline Variabel Input & Definisi & Referensi \\
\hline Biaya Komisi $\left(\mathrm{X}_{1}\right)$ & $\begin{array}{l}\text { Biaya jasa yang diberikan kepada agen } \\
\text { atau broker oleh perusahaan asuransi. }\end{array}$ & $\begin{array}{l}\text { Saad et al. (2006), Tuffahati et al. } \\
\text { (2016), Rahman (2013), Abduh, et al } \\
\text { (2012), Mandal dan Dastidar (2014) }\end{array}$ \\
\hline $\begin{array}{l}\text { Biaya Operasional } \\
\left(\mathrm{X}_{2}\right)\end{array}$ & $\begin{array}{l}\text { Biaya berkelanjutan dari suatu kegiatan } \\
\text { bisnis perusahaan asuransi. Yaitu, biaya } \\
\text { sehari-hari yang diperlukan untuk } \\
\text { menjalankan perusahaan di mana } \\
\text { termasuk biaya lisensi, biaya kantor, dan } \\
\text { lain-lain. }\end{array}$ & $\begin{array}{l}\text { Hu et al. (2009), Mandal dan } \\
\text { Dastidar (2014) }\end{array}$ \\
\hline Ekuitas $\left(X_{3}\right)$ & $\begin{array}{l}\text { Modal ekuitas menunjukkan uang yang } \\
\text { tidak dibayarkan kepada para investor. } \\
\text { Hal ini mewakili modal risiko yang } \\
\text { dipertaruhkan oleh investor melalui } \\
\text { pembelian saham biasa perusahaan. }\end{array}$ & $\begin{array}{l}\text { Hu et al. (2009), Borges et al. (2008), } \\
\text { Eling dan Luhnen (2008), Mandal } \\
\text { dan Dastidar (2014) }\end{array}$ \\
\hline Total premi & $\begin{array}{l}\text { Jumlah total premi yang menjadi } \\
\text { kewajiban peserta asuransi untuk porsi } \\
\text { risiko dan ujrah yang dibayarkan kepada } \\
\text { perusahaan asuransi }\end{array}$ & $\begin{array}{l}\text { Saad et al. (2006), Tuffahati et al. } \\
\text { (2016), Rahman (2013), Abduh, et al } \\
\text { (2012), Hu et al. (2009), Mandal dan } \\
\text { Dastidar (2014) }\end{array}$ \\
\hline $\begin{array}{l}\text { Pendapatan } \\
\text { investasi }\end{array}$ & $\begin{array}{l}\text { Hasil yang didapatkan dari kegiatan } \\
\text { investasi atas harta yang dimiliki }\end{array}$ & $\begin{array}{l}\text { Saad et al. (2006), Tuffahati et al. } \\
\text { (2016), Rahman (2013), Abduh, et al } \\
\text { (2012), Mandal dan Dastidar (2014) }\end{array}$ \\
\hline
\end{tabular}

\section{ANALISIS DAN PEMBAHASAN}

Pengolahan data untuk memperoleh skor efisiensi dari DMU menggunakan Software MaxDEA. DMU dapat dinyatakan telah mencapai efisiensi relatif apabila dapat mencapai skor 1 atau 100 persen dan semakin tidak efisien apabila semakin kurang dari 1 atau 100 persen.

Berdasarkan hasil olah data dengan menggunakan software MaxDEA, didapatkan hasil dengan asumsi CRS dan VRS, maka dari itu dapat disimpulkan bahwa kinerja asuransi jiwa konvensional dan syariah di Indonesia selama tahun 2012-2019 belum efisien, baik secara ekonomi, teknik, maupun skala. Dari 48 DMU yang diukur dan terdiri dari 24 DMU asuransi jiwa konvensional dan 24 DMU asuransi jiwa syariah. Dalam asuransi jiwa konvensional terdapat enam DMU efisien secara ekonomi, 12 DMU efisien secara teknis, dan enam DMU efisiensi secara skala.

Sisanya menunjukkan skor yang cukup beragam dan tidak efisien: 18 DMU secara ekonomi, 12 DMU secara teknis, dan delapan DMU secara skala. Jika dilihat dalam asuransi jiwa syariah, hanya empat DMU yang efisien secara teknis. Tidak terdapat DMU yang efisien baik secara ekonomi dan skala.

Tabel 5

Sebaran Efisiensi Asuransi Jiwa Konvensional dan Syariah (dalam satuan unit)

\begin{tabular}{ccccccc}
\hline \hline & \multicolumn{3}{c}{ Asuransi Jiwa Konvensional } & \multicolumn{3}{c}{ Asuransi Jiwa Syariah } \\
\cline { 2 - 7 } Skor Efisiensi & CRS & VRS & Scale & CRS & VRS & Scale \\
\hline 1 & 6 & 12 & 6 & 0 & 4 & 0 \\
0,0001-0,9999 & 18 & 12 & 18 & 24 & 20 & 24 \\
Total & 24 & 24 & 24 & 24 & 24 & 24 \\
Rata-rata & 0,648209 & 0,7222005 & 0,814473 & 0,172613 & 0,474148 & 0,537069 \\
\hline
\end{tabular}

Sumber: Data Hasil Penelitian (diolah) 
Berdasarkan pemaparan di atas, dapat disimpulkan bahwa sebagian asuransi jiwa baik konvensional maupun syariah masih belum efisien. Nilai rata-rata efisiensi asuransi jiwa konvensioanal secara ekonomi sebesar 64,82 persen, secara teknis sebesar 72,22 persen, dan secara skala sebesar 81,44 persen. Sedangkan nilai rata-rata efisiensi asuransi jiwa syariah secara ekonomi sebesar 17,26 persen, secara teknis sebesar 47,41 persen, dan secara skala sebesar 53,71 persen. Sumber ketidakefisienan perusahaan asuransi jiwa konvensional dan syariah ini disebabkan oleh pengelolaan input dan output, serta skala usaha yang belum optimal. Jika dilihat dari tren rata-rata skor efisiensi baik secara CRS, VRS, dan Skala yang ditinjau dari orientasi input, maka pada tingkat output (premi dan pendapatan investasi) tersebut, input yang dimiliki masih bisa dikurangi dan bila ditinjau dari orientasi output, maka dengan input (biaya komisi, biaya operasional, dan ekuitas) yang dimiliki oleh setiap DMU, hasil output seharusnya bisa lebih besar dari jumlah premi dan pendapatan investasi yang ada saat ini. Jika dilihat dari tren rata-rata efisiensi asuransi jiwa konvensional dari tahun 2012 skor efisiensi asuransi jiwa konvensional secara ekonomis (CRS) cenderung berfluktuasi dengan tren yang positif selama rentang periode penelitian. Hal ini dilihat dari pergerakan kurva CRS yang menurun cukup dalam pada periode awal penelitian sebesar
79,83 persen (2012) hingga menyentuh 38,62 persen (2014), lalu meningkat selama dua periode kemudian 64,09 persen (2015) dan 71,89 persen (2016), kemudian pada 2017 mengalami penurunan kembali hingga 58,19 persen, dan dua periode terakhir mengalami peningkatan 63,17 persen (2018) dan 72,30 persen (2019). Sedangkan untuk skor efisiensi secara teknis (VRS) selama rentang periode penelitian memiliki slope yang negatif dan cenderung stabil, dimana pada dua periode awal cenderung menurun relative dalam dari 80,79 persen (2012) hingga 70,98 persen (2013), lalu meningkat pada dua periode berikutnya menjadi 72,17 (2014) dan 72,43 persen (2015), pada 2 periode kembali menurun dengan nilai efisiensi sebesar 71,90 (2016) dan 69,18 persen (2017) dan dua periode terakhir kembali dengan tren yang positif 69,37 persen (2018) dan 70,44 persen (2019). Untuk skor efisiensi secara skala selama rentang periode penelitian juga mengalami fluktuasi, pada awal periode skor efisiensi meningkat dari 98,02 persen (2012) dan 98,67 persen (2013), lalu 2014 mengalami penurunan yang tajam menjadi 63,33 persen (2014), pada periode berikutnya mengalami peningkatan kembali hingga 85,52 persen (2015), lalu skor efisiensi menunjukkan penurunan selama tiga periode kedepan 83,57persen (2016); 73,36 persen (2017) dan 71,83 persen (2018), namun di periode terakhir mengalami peningkatan menjadi 76,94 persen (2019).

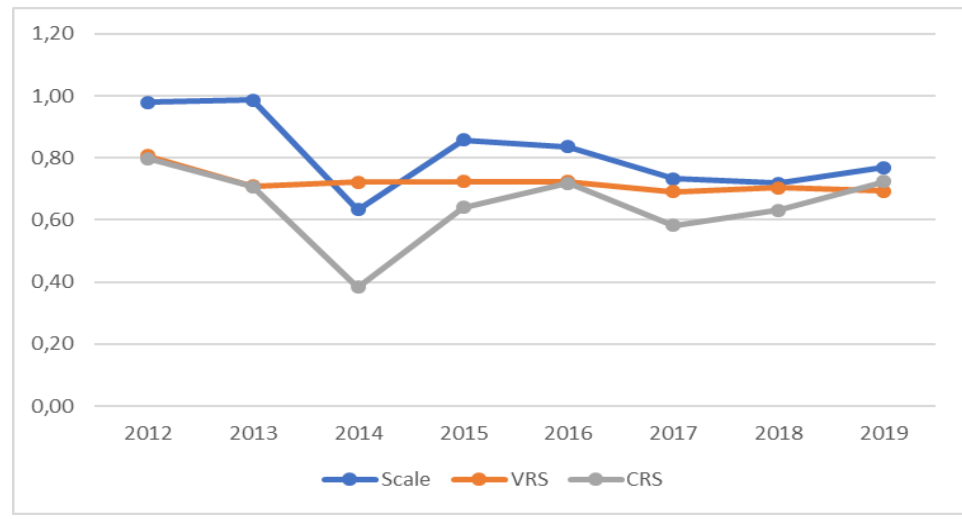

Gambar 2

Tren Rata-rata Efisiensi Asuransi Jiwa Konvensional 2012-2019

Sumber: Data Hasil Penelitian (diolah) 
Jika dilihat dari tren rata-rata efisiensi asuransi jiwa syariah selama rentang periode penilitian, skor efisiensi asuransi jiwa syariah secara ekonomis (CRS) menunjukkan tren yang menurun, pada dua periode pertama menurun relative dalam, yaitu 33,56 persen (2012); 19,44 (2013); dan 18,57 persen (2014). Pada 2015 skor efisiensi kembali meningkat menjadi 20,76 persen, untuk empat periode terakhir penurunannya kembali dalam dari 15,68 persen (2016) hingga mencapai 8,04 persen (2019).

Untuk skor efisiensi secara teknis (VRS) berfluktuasi yang memiliki tren negatif. Hal ini ditunjukkan oleh kurva VRS yang menurun relatif dalam pada tiga periode pertama, yaitu 83,57 persen (2012); 73,36 persen (2013); dan 34,30 persen (2014), namun pada 2015 skor efisiensi kembali meningkat menjadi 64,99 persen, pada dua periode kemudian menurun kembali 52,15 persen (2016) menjadi 44,51 persen (2017) dan sedangkan dua periode terakhir mengalami peningkatan dari 50,48 persen (2018) dan 52,85 persen (2019).

Untuk skor efisiensi secara skala selama rentang periode penelitian juga mengalami fluktuasi dengan tren yang menurun, pada awal periode skor efisiensi menurun dari 47,82 persen (2012) menjadi 43,45 persen (2013), lalu 2014 mengalami peningkatan yang relative tinggi menjadi 62,76 persen (2014), namun pada periode berikutnya skor efisiensi kembali mengalami penurunan hingga 42,59 persen (2015), lalu dua periode kedepan menunjukkan peningkatan 46,90 persen (2016) dan 47,89 persen (2017), namun di dua periode terakhir mengalami penurunan menjadi 46,62 persen (2018) dan menjadi 41,26 persen (2019).

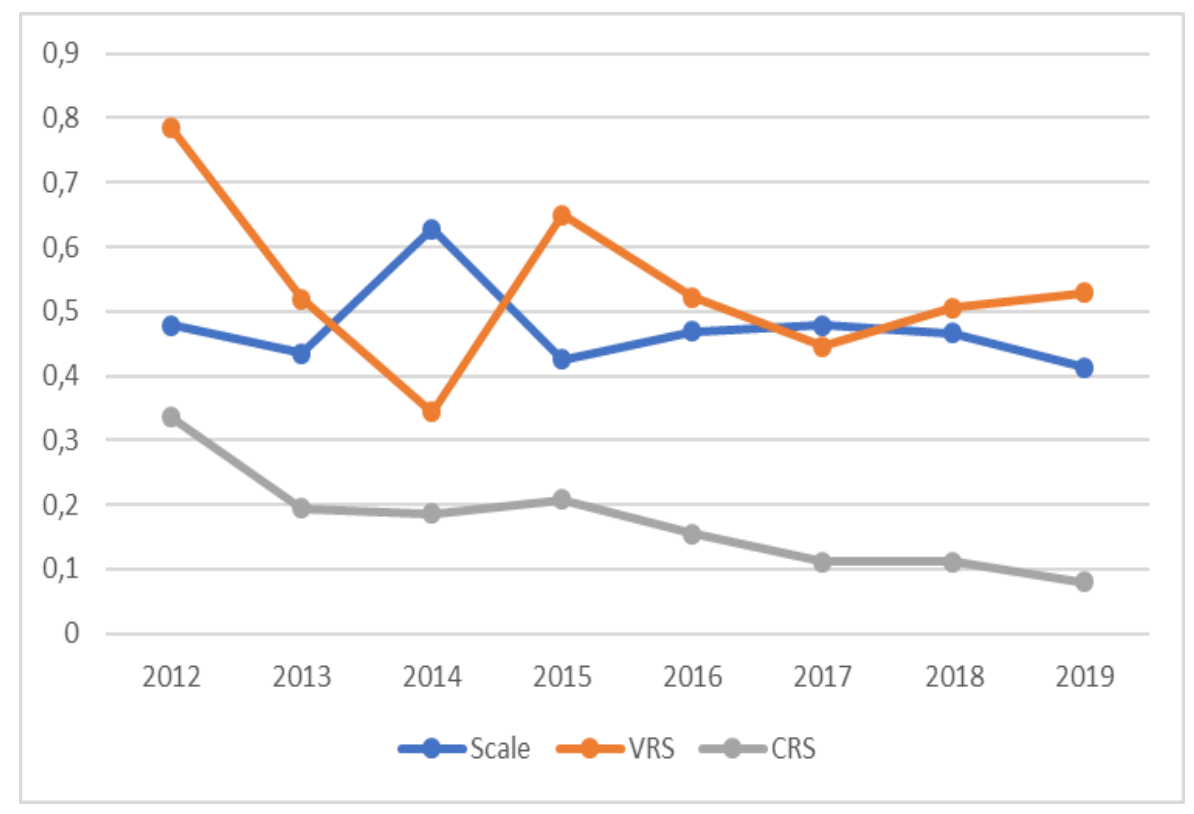

Gambar 3

Tren Rata-rata Efisiensi Asuransi Jiwa Syariah, 2012-2016

Sumber: Data Hasil Penelitian (diolah)

Ketika membandingkan antara tren rata-rata tingkat efisiensi asuransi jiwa syariah drelatif lebih rendah dibandingkan dengan asuransi jiwa konvensional. Namun secara keseluruhan, tren rata-rata efisiensi tersebut menggambarkan bahwa kinerja asuransi jiwa baik konvensional maupun syariah secara ekonomi, teknis, dan skala cenderung menurun meski ada yang mengalami kenaikan. Berikut ini adalah daftar perusahaan asuransi jiwa konvensional dan syariah yang efisien selama 2012-2019: 
Tabel 6

Daftar Perusahaan yang Efisien

\begin{tabular}{lll}
\hline & CRS (Ekonomi) dan Scale Efficiency & \multicolumn{1}{c}{ VRS (Teknik) } \\
\hline Asuransi Jiwa & PT Asuransi Jiwasraya (Persero), dan & $\begin{array}{l}\text { PT Asuransi Jiwasraya (Persero), } \\
\text { dan PT Asuransi Prudential }\end{array}$ \\
$\begin{array}{l}\text { Konvensional } \\
\text { Syaransi Jiwa }\end{array}$ & PT Asuransi Prudential & PT Asuransi Jiwa Al-Amin \\
\hline
\end{tabular}

Sumber: Data Hasil Penelitian (diolah)

Besarnya komposisi jumlah DMU yang efisien secara ekonomi pada masing-masing perusahaan asuransi jiwa konvensional adalah empat di Asuransi Jiwasraya, dan dua di Prudential Life. Tidak ada DMU yang efisien untuk asuransi Axa Life. Pada perusahaan asuransi jiwa syariah, diantaranya Asuransi Takaful Keluarga, Asuransi Jiwa Al-Amin, dan Asuransi Amanahjiwa Giri Artha tidak ada DMU yang efisien secara ekonomi. Untuk komposisi jumlah DMU yang efisien secara skala pada masingmasing perusahaan asuransi jiwa konvensional adalah empat di Asuransi Jiwasraya, dan dua di Prudential Life. Tidak ada DMU yang efisien secara skala untuk asuransi Axa Life. Sedangkan pada perusahaan asuransi jiwa syariah, diantaranya Asuransi Takaful Keluarga, Asuransi Jiwa Al-Amin, dan Asuransi Amanahjiwa Giri Artha tidak ada DMU yang efisien secara skala.
Komposisi DMU yang efisien scara teknik pada masing-masing perusahaan asuransi jiwa konvensional adalah enam di Asuransi Jiwasraya, dan enam di Asuransi Prudetial Life. Tidak ada DMU yang efisien untuk asuransi Axa Life. Pada perusahaan asuransi jiwa syariah, terdapat satu di Asurasi Al-Amin, dan tiga di Asuransi Amanahjiwa Giri Artha.

Tidak ada DMU efisien pada Asuransi Takaful Keluarga. Dengan metode DEA juga mampu mengukur dan memastikan apakah sebuah DMU sudah mengoptimalkan kapasitas produksinya, yakni seberapa optimal penggunaan input dalam menghasilkan output. Dalam hal ini, suatu DMU akan memiliki salah satu dari tiga kondisi Return To Scale (RTS), di antaranya adalah Incresing Return to Scale (IRS), Constant Return to Scale (CRS), dan Decreasing Return to Scale (DRS).

Tabel 7

Daftar Rate of Return Asuransi Jiwa Konvensional dan Asuransi Jiwa Syariah

\begin{tabular}{lccl}
\hline \multicolumn{1}{c}{ Return To Scale } & $\begin{array}{c}\text { Asuransi Jiwa } \\
\text { Konvensional }\end{array}$ & $\begin{array}{c}\text { Asuransi Jiwa } \\
\text { Syariah }\end{array}$ & Persentase \\
\hline Incresing Return to Scale & 3 & 24 & $27(56,25 \%)$ \\
Constant Return to Scale & 10 & 0 & $10(20,83 \%)$ \\
Decreasing Return to Scale & 11 & 0 & $11(22,92 \%)$ \\
Total & 24 & 24 & $48(100 \%)$ \\
\hline
\end{tabular}

Sumber: Data Hasil Penelitian (diolah)

Hasil pengolahan data menunjukkan bahwa ada 27 DMU atau 56,25 persen yang terdiri dari tiga DMU Asuransi Jiwa Konvensional dan 24 DMU Asuransi Jiwa Syariah berada dalam kondisi IRS.
Kemudian 10 DMU atau 20,83 persen yang terdiri dari Asuransi Jiwa Konvensional yang mengalami kondisi DRS. Sedangkan sisanya 11 DMU atau 22,92 persen yang terdiri dari Asuransi Jiwa Konvensional 
yang berada dalam kondisi CRS. Kondisi IRS memungkinkan untuk terus meningkatkan kapasitas hasil output dengan mempertahankan input yang ada, karena penambahan input justru tidak efektif mengingat sumber daya yang digunakan masih belum berfungsi secara optimal. Adapun kondisi DRS menuntut adanya pengurangan input, karena jumlah input dengan output yang dihasilkan sudah tidak ideal.

Dari hasil di atas dapat diketahui bahwa, perusahaan asuransi jiwa syariah memiliki efisiensi yang lebih rendah dibanding dengan perusahaan asuransi jiwa konvensional. Hal ini dikarenakan masih kurangnya kemampuan perusahaan Asuransi Syariah dalam meningkatkan kinerjanya dan melakukan inovasi dalam kegiatan bisnisnya sehingga masih kalah dari perusahaan Asuransi Jiwa Konvensional.

\section{Potential Improvement}

Hasil perhitungan efisiensi DEA sebagaimana telah dijabarkan di atas, bahwa baik dari orientasi input maupun orientasi output telah menghasilkan skor efisiensi yang relatif berbeda. Akan tetapi, untuk mendeteksi sumber inefisiensinya, diperlukan kedua pendekatan tersebut untuk menghasilkan analisis input dan output yang harus ditingkatkan atau dikurangi pada kedua pendekatan. Dari skor rata-rata efisiensi enam perusahaan asuransi jiwa baik konvensional maupun syariah, asuransi jiwa Takaful Keluarga yang memiliki skor paling kecil sehingga perbaikan dapat dilakukan untuk perusahaan ini.

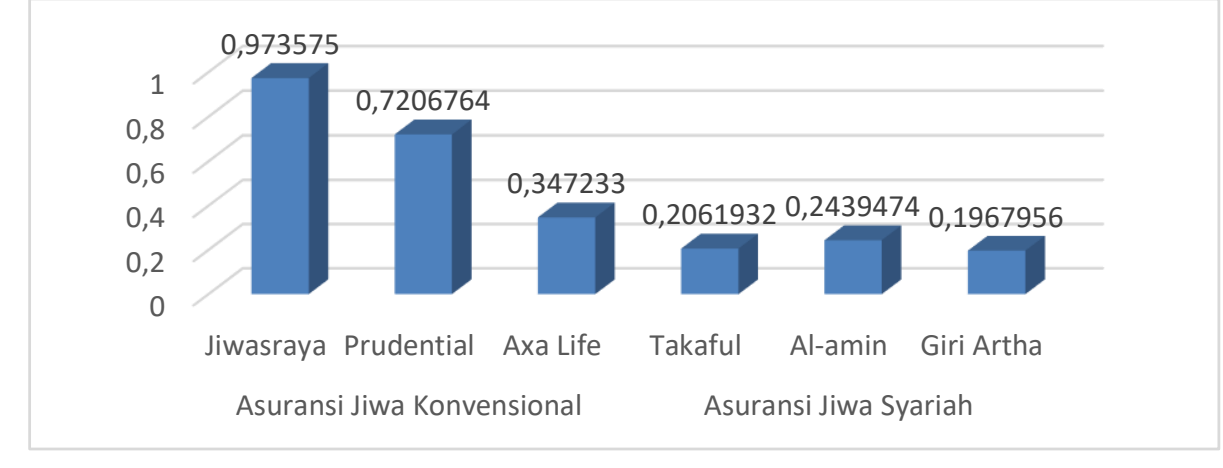

\section{Gambar 4 \\ Pencapaian Tingkat Efisiensi Ekonomi Rata-rata Pada Masing-masing Asuransi Jiwa secara CRS}

Sumber: Data Hasil Penelitian (diolah)

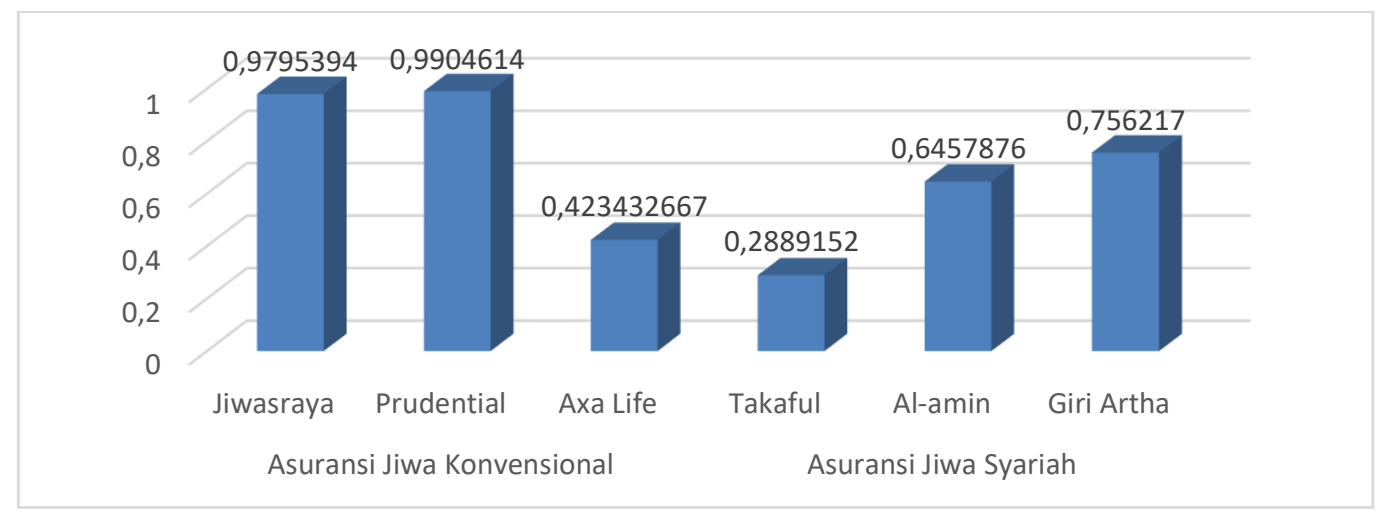

Gambar 5

Pencapaian Tingkat Efisiensi Ekonomi Rata-rata Pada Masing-masing Asuransi Jiwa secara VRS

Sumber: Data Hasil Penelitian (diolah) 
Pada perusahaan Asuransi Takaful Keluarga belum menunjukkan efisien sama sekali dari 2012-2019, padahal perusahaan ini adalah pionir perusahaan asuransi syariah di Indonesia. Untuk mendapatkan hasil yang efisien, asuransi Takaful Keluarga harus mengurangi jumlah input, sekaligus meningkatkan output untuk menghasilkan output yang ideal oleh DMU pada tahuntahun tersebut (Sabiti et al., 2017). Karena, pada rata-rata improvement input oriented CRS Asuransi Takaful Keluarga harus menurunkan biaya komisi sebesar 57,16 persen, di mana dengan penurunan biaya komisi yang diberikan kepada para agen diharapkan akan dapat meningkatkan output sehingga perusahaan menjadi efisien, 59,63 persen biaya operasional, seperti halnya dengan penurunan biaya komisi, agar perusahaan asuransi menjadi efisien (Benarda et al.,
2016), perusahaan harus menurunkan biaya operasional yang dikeluarkan oleh perusahaan, dan 50,15 persen pada ekuitas, sama halnya seperti kedua variabel input di atas, penurunan pada ekuitas juga diperlukan (Tuffahati, Mardian, dan Suprapto, 2017). Sedangkan pada rata-rata improvement output oriented CRS Asuransi Takaful harus menurunkan biaya operasional 6,08 persen, meningkatkan sebesar 282,95 persen premi, dan 363,63 persen pendapatan investasi dari rata-rata aktual pada masing-masing variabel. Dengan meningkatkan premi dan pendapatan investasi pada asuransi Jiwa Takaful maka diharapkan dapat mencapai tingkat efisiensi yang maksimal, karena pendapatan investasi merupakan hal penting yang dapat memberikan tambahan pada laporan Surplus (Defisit) Underwiting Dana Tabarru'.

Tabel 8

Potential Improvement CRS Input and Output Oriented Asuransi Takaful Keluarga (dalam juta Rupiah)

\begin{tabular}{|c|c|c|c|c|c|c|}
\hline \multicolumn{7}{|c|}{ PT Asuransi Takaful Keluarga } \\
\hline \multirow[t]{2}{*}{ Variabel } & \multicolumn{2}{|c|}{$\begin{array}{l}\text { Rata-rata (Orientasi } \\
\text { Input) }\end{array}$} & \multirow[t]{2}{*}{ Persen } & \multicolumn{2}{|c|}{$\begin{array}{c}\text { Rata-rata (Orientasi } \\
\text { Output) }\end{array}$} & \multirow[t]{2}{*}{ Persen } \\
\hline & Aktual & Target & & Aktual & Target & \\
\hline Biaya Komisi & 57576 & 24665,6765 & 57,15979 & 57576 & 57576 & 0 \\
\hline Biaya Operasional & 58684,8 & 23687,2679 & 59,63645 & 58684,8 & 55117,2216 & 0,060792 \\
\hline Ekuitas & 156483,6 & 78000,877 & 50,15396 & 156483,6 & 156483,6 & 0 \\
\hline Premi & 115979 & 115979 & 0 & 114824 & 324900,235 & 282,95 \\
\hline $\begin{array}{l}\text { Pendapatan } \\
\text { Investasi }\end{array}$ & 14165,75 & 14165,75 & 0 & 14563,4 & 52957,1504 & 363,63 \\
\hline
\end{tabular}

Sumber: Data Hasil Penelitian (diolah)

\section{Improvement CRS (Orientasi Input atau Output)}

Pada perusahaan Asuransi Takaful Keluarga belum menunjukkan efisien sama sekali dari 2012-2019, padahal perusahaan ini adalah pionir perusahaan asuransi syariah di Indonesia. Untuk mendapatkan hasil yang efisien, asuransi Takaful Keluarga harus mengurangi jumlah input, sekaligus meningkatkan output untuk menghasilkan output yang ideal oleh DMU pada tahuntahun tersebut (Khan dan Nooren, 2014).
Pada rata-rata improvement input oriented CRS Asuransi Takaful Keluarga harus menurunkan biaya komisi sebesar 79,11 persen, 79,62 persen biaya operasional, dan 79,62 persen pada ekuitas.

Sedangkan pada rata-rata improvement output oriented CRS Asuransi Takaful harus menurunkan biaya operasional 0,74 persen, meningkatkan sebesar 489,34 persen premi, dan 499,66 persen pendapatan investasi dari rata-rata aktual pada masing-masing variabel. 
Tabel 9

Potential Improvement VRS Input and Output Oriented Asuransi Takaful Keluarga (dalam juta Rupiah)

\begin{tabular}{|c|c|c|c|c|c|c|}
\hline \multicolumn{7}{|c|}{ PT Asuransi Takaful Keluarga } \\
\hline \multirow{2}{*}{ Variabel } & \multicolumn{2}{|c|}{$\begin{array}{c}\text { Rata-rata (Orientasi } \\
\text { Input) }\end{array}$} & \multirow{2}{*}{ Persen } & \multicolumn{2}{|c|}{$\begin{array}{c}\text { Rata-rata (Orientasi } \\
\text { Output) }\end{array}$} & \multirow{2}{*}{ Persen } \\
\hline & Aktual & Target & & Aktual & Target & \\
\hline Biaya Komisi & 57576 & 12023,649 & 79,1169081 & 57576 & 57576 & 0 \\
\hline Biaya Operasional & 58684,8 & 12011,706 & 79,5318277 & 58684,8 & 58250,04 & 0,007408381 \\
\hline Ekuitas & 156483,6 & 31885,9719 & 79,6234417 & 156483,6 & 156483,6 & 0 \\
\hline Premi & 115979 & 115979 & 0 & 115979 & 567530,1 & $-489,34$ \\
\hline $\begin{array}{l}\text { Pendapatan } \\
\text { Investasi }\end{array}$ & 14563,4 & 14563,4 & 0 & 14563,4 & 72767,98 & $-499,66$ \\
\hline
\end{tabular}

Sumber: Data Hasil Penelitian (diolah)

\section{SIMPULAN DAN SARAN}

Dari enam Asuransi jiwa baik konvensional maupun syariah, secara rata untuk DMU belum menunjukkan efisien. Pada asuransi jiwa konvensional, skor efisiensi secara ekonomis (CRS) adalah sebesar 64,82 persen, secara teknis sebesar 72,22 persen, dan secara skala sebesar 81,44 persen. Sedangkan nilai rata-rata efisiensi asuransi jiwa syariah secara ekonomi sebesar 17,26 persen, secara teknis sebesar 47,41 persen, dan secara skala sebesar 53,70 persen. Kemudian dari tren efisiensi asuransi jiwa baik konvensional dan syariah menunjukkan bahwa pengelolaannya sama-sama masih fluktuatif sehingga masih perlu ditingkatkan agar lebih efisien.

Perbandingan efisiensi antara asuransi jiwa konvensional dan syariah adalah besarnya komposisi jumlah DMU yang efisien secara ekonomi pada masing-masing perusahaan asuransi jiwa konvensional adalah empat di Asuransi Jiwasraya, dan dua di Prudential Life. Tidak ada DMU yang efisien untuk asuransi Axa Life. Pada perusahaan asuransi jiwa syariah, diantaranya Asuransi Takaful Keluarga, Asuransi Jiwa Al-Amin, dan Asuransi Amanahjiwa Giri Artha tidak ada DMU yang efisien. Komposisi jumlah DMU yang efisien secara skala pada masing-masing perusahaan asuransi jiwa konvensional adalah empat di Asuransi Jiwasraya, dan dua di Prudential Life. Tidak ada DMU yang efisien secara skala untuk asuransi Axa Life. Sedangkan pada perusahaan asuransi jiwa syariah, diantaranya Asuransi Takaful Keluarga, Asuransi Jiwa Al-Amin, dan Asuransi Amanahjiwa Giri Artha tidak ada DMU yang efisien secara skala. Komposisi DMU yang efisien secara teknik pada masing-masing perusahaan asuransi jiwa konvensional adalah enam di Asuransi Jiwasraya, dan enam di Asuransi Prudetial Life. Tidak ada DMU yang efisien untuk asuransi Axa Life. Pada perusahaan asuransi jiwa syariah, terdapat satu di Asurasi Al-Amin, dan tiga di Asuransi Amanahjiwa Giri Artha. Tidak ada DMU efisien pada Asuransi Takaful Keluarga

Selanjutnya, dari hasil pengolahan data menunjukkan bahwa ada 27 DMU atau 56,25 persen yang terdiri dari tiga DMU Asuransi Jiwa Konvensional dan 24 DMU Asuransi Jiwa Syariah berada dalam kondisi IRS. Kemudian 10 DMU atau 20,83 persen yang terdiri dari Asuransi Jiwa Konvensional yang mengalami kondisi DRS. Sedangkan sisanya 11 DMU atau 22,92 persen yang terdiri dari Asuransi Jiwa Konvensional yang berada dalam kondisi CRS.

Berdasarkan kesimpulan peneltian, maka terdapat beberapa implikasi yang dapat menjadi masukan dan pertimbangan untuk mengoptimalkan potensi yang dimiliki oleh asuransi baik konvensional dan syariah, sebagai berikut: (1) Dalam tatanan teknis pelaksanaan operasional BPRS, praktik corporate governance asuransi perlu 
untuk ditingkatkan lagi, sehingga keper0 cayaan masyarakat untuk menggunakan jasa asuransi semakin meningkat; (2) untuk mengoptimalkan nilai efisiensinya, perusahaan baik konvensional dan syariah asuransi perlu untuk menurunkan biaya komisi, di mana dengan penurunan biaya komisi yang diberikan kepada para agen diharapkan akan dapat meningkatkan, selain itu perusahaan asuransi perlu untuk meningkatkan premi dan pendapatan investasi sehingga nilai efisiensinya akan meningkat. Rekomendasi untuk perbaikan perhitungan efisiensi kedepannya: (1) menggunakan data yang lebih rinci seperti mingguan atau bulanan sehingga perhitungan efisiensi dapat dikembangkan lagi; (2) sampel yang digunakan dalam penelitian ini hanya berjumlah enam asuransi jiwa di Indonesia yang terdiri dari tiga perusahaan asuransi jiwa konvensional dan tiga perusahaan asuransi jiwa syariah, oleh karena itu penelitian selanjutnya sebaiknya dapat menggunakan seluruh populasi asuransi jiwa, sehingga hasil yang diperoleh dapat lebih mewakili industri jiwa di Indonesia.

\section{DAFTAR PUSTAKA}

Abduh, M., M. A. Omar, dan R. M. Tarmisi. 2012. The Performance of Insurance Industry in Malaysia: Islamic vis-a-vis Conventional Insurance. Journal of Islamic Banking and Finance 29(4): 40-9.

Abror, A., O. E. Santi, dan P Frianto. 2005. Lembaga Keuangan. Rineka Cipta. Jakarta.

Ahmad, R. dan A. Hamid. 2008. Lembaga Keuangan Syariah. Zikrul Hakim. Jakarta.

Ali, Z. 2008. Hukum Asuransi Syariah. Sinar Grafika. Jakarta.

Aliyu, S. dan R. M. Yusof. 2016. Profitability and Cost Efficiency of Islamic Banks: A Panel Analysis of Some Selected Countries. International Journal of Economics and Financial Issues 6(4): 1736-1743.

Alqahtani, F., D. G. Mayes dan K. Brown. 2017. Islamic Bank Efficiency Compared to Conventional Banks during the
Global Crisis in the GCC Region. Journal of International Financial Markets, Institutions and Money 51: 58-74.

Al-Qur'an dan Terjemahnya. 2009. PT. Sygma Examedia Arkanleema. Bandung.

Amrin, A. 2006. Asuransi Syariah: Keberadaanya dan Kelebihannya di Tengah Asuransi Konvensional. IKAPI. Jakarta.

Archer, T. S. 2010. The Efficiency Theory. TSA. http://www. theefficiency theory.com/ The_Efficiency_Theory.pdf.

Banker R. D., A. Charnes dan W. W. Cooper 1984. Some Models for Estimating Technical and Scale Inefficiencies in Data Envelopment Analysis. Management Science 30(9): 1078-92

Banker, R., W. Cooper, L. M. Seiford, dan J. Zhu. 2012. Risk Analysis in Stochastic Supply Chains - A Mean Apporach. International Series in Operations Research $\mathcal{E}$ Management Science 178.

Benarda, B., U. Sumarwan, dan M. N. Hosen. 2016. Tingkat Efisiensi Industri Asuransi Jiwa Syariah Menggunakan Pendekatan Two Stage Data Envelopment Analysis. Jurnal Aplikasi Bisnis dan Manajemen 2(1): 64-72.

Borges, M., M. Nektarios, dan C. Barros 2008. Analysing the Efficiency of the Greek Life Insurance Industry. European Research Studies Journal 11(3): 35-52.

Charnes, A., W. W. Cooper, dan E. Rhodes. 1978. Measuring the Efficiency of Decision Making Units. European Journal of Operation Research 2: 429-44

Dewi, K. dan R. Siauwijaya. 2016. Analisis Efisiensi Teknis Perbankan di Indonesia. Jurnal Manajemen 13(2): 132-148.

Eling, M. dan M. Luhnen. 2008. Frontier Efficiency Methodologies to Measure Performance in the Insurance Industry: Overview and New Empirical Evidence. The Geneva Papers on Risk and Insurance Issues and Practice 35(2): 217-265.

Farrel, M. 1957. The Measurement of Productive Efficency. Jurnal of the Royal Statistical Society 120(3): 253-290. 
Faruk, M. O. dan A. Rahaman. 2015. Measuring Efficiency of Conventional Life Insurance Companies in Bangladesh and Takaful Life Insurance Companies in Malaysia: A NonParametric Approach. Journal of Management Studies and Economic System 2(2): $129-44$.

Hu, X., C. Zhang, dan N. Zhu. 2009. Analyzing Efficiency in the Chinese Life Insurance Industry. Management Research News 32(10): 905-920.

Karim, A. 2007. Ekonomi Mikro Islam. Raja Grafindo Persada. Jakarta.

Khan, A. dan U. Noreen. 2014. Efficiency Measure of Insurance vs Takaful Firms Using DEA Approach: A Case of Pakistan. Islamic Economic Studies 22(1): 139-158.

Galiniene, B. dan G. Dzemydaite. 2012. Spatial Data Envelopment Analysis Method for the Evaluation of Regional Infrastructure Disparities. Social Technologies 2(2): 390-403.

Mandal, S. dan S. G. Dastidar. 2014. A DEAInvestigation of Efficiency of the Indian General Insurance during Recession. Journal of Advances in Management Research 11(1): 115-136.

Miah, Dulal Mohammad dan Uddin, Helal. 2017. Efficiency and Stability: A Comparative Study between Islamic and Conventional Banks in GCC Countries. Future Business Journal 3: 172-185

Muhammad. 2007. Lembaga Ekonomi Syariah. Graha Ilmu. Yogyakarta.

Muharam, H. dan R. Pusvitasari. 2007. Analisis Perbandingan Efisiensi Bank Syariah di Indonesia Dengan Metode Data Envelopment Analysis (periode Tahun 2005). Jurnal Ekonomi Dan Bisnis Islam II(3): 80-166.

Ningsih, Y. W. dan N. Suprayogi. 2017. Analisis Efisiensi Asuransi Umum Syariah di Indonesia Tahun 2013-2015: Aplikasi Metode Data Envelopment Analysis (DEA). Jurnal Ekonomi Syariah Teori dan Terapan 4(9): 757-772.
Novandra, R. 2014. Analisis Perbandingan Efisiensi Perbankan Syariah dan Konvensional di Indonesia. Jurnal Ekonomi dan Pembangunan 22(2): 183-193.

Otoritas Jasa Keuangan. 2016. Statistik Peransuransian 2016. Otoritas Jasa Keuangan. Jakarta.

Putri, M. S. dan A. S. Mulazid. 2017. Analisis Efisiensi Bank Umum Syariah (BUS) Di Indonesia Dengan Menggunakan Metode Data Envelopment Analysis (DEA) Periode 2013-2015. Al-Mabsut: Jurnal Studi Islam Dan Siosal 11(1): 1-17.

Rahman, M. A. 2013. Comparative Study on the Efficiency of Bangladeshi Conventional and Islamic Life Insurance Industry: A Non-Parametric Approach. Asian Business Review 2(3): 88-99.

Rosman, R., N. A. Wahab, dan Z. Zainol. 2013. Efficiency of Islamic Banks during the Financial Crisis: An Analysis of Middle Eastern and Asian Countries. Pacific-Basin Finance Journal: 1-29.

Rusydiana, A. S. dan T. Nugroho. 2017. Measuring Efficiency of Life Insurance Institution in Indonesia: Data Envelopment Analysis Approach. Global Review of Islamic Economics and Business 5(1): 1224.

Saad, N. M., M. S. A. Majid, R. M. Yusof, J. Duasa, dan A. R. A. Rahman. 2006. Measuring Efficiency of Insurance and Takaful Companies in Malaysia Using Data Envelopment Analysis (DEA). Review of Islamic Economics 10(2): 5-26.

Sabiti, M. B., J. Effendi, dan T. Novianti 2017. Efisiensi Asuransi Syariah di Indonesia dengan Pendekatan Data Envelopment Analysis. Jurnal Al-Muzara'ah 5(1): 69-87.

Sutawijaya, A. dan E. P. Lestari. 2009. Efisiensi Teknik Perbankan Indonesia Pascakrisis Ekonomi: Sebuah Studi Empiris Penerapan Model DEA. Jurnal Ekonomi Pembangunan: Kajian Masalah Ekonomi dan Pembangunan 10(1): 49.

Tuffahati, H., S. Mardian, dan E. Suprapto. 2016. Pengukutan Efisiensi Asuransi Syariah dengan Data Envelopment 
Analysis (DEA). Jurnal Akuntansi dan Keuangan Islam 4(1): 1-24.

Tumbel, T. M. 2014. Analisis Bantuan Desa Terhadap Pelaksanaan Pembangunan Desa (Studi Kasus Pada Kecamatan Tareran Kabupaten Minahasa Selatan). Jurnal LPPM Bidang EkoSosBudKum 1(2): 1-12.

Utama, A. P., H. Wahyono, dan M. Witjaksono. 2016. Efisiensi Pengambilan
Keputusan Sumber Daya Ekonomi Konsumsi Produksi Mahasiswa. Jurnal Pendidikan: Teori, Penelitian, Dan Pengembangan 1(4): 712-716.

Winarno, S. H. 2015. Analisis Perbandingan Asuransi Syariah dan Asuransi Konvensional. Moneter: Jurnal Akuntansi dan Keuangan 2(2): 17-28.

Wirdyaningsih. 2005. Bank dan asuransi Islam di Indonesia. Prenada Media. Jakarta. 